\title{
Development and testing of an algorithm for calculating the load on support of mine workings
}

\author{
Volodymyr Bondarenko $^{1 \otimes(\odot)}$, Iryna Kovalevska ${ }^{1 * \otimes(\bullet}$, Frederick Cawood ${ }^{2 \otimes}$, \\ Oleksandr Husiev $^{3 \otimes}$, Vasyl Snihur ${ }^{4 \bowtie}$, Dennis Jimu ${ }^{2 \otimes}$ (1) \\ ${ }^{1}$ Dnipro University of Technology, Dnipro, 49005, Ukraine \\ ${ }^{2}$ University of the Witwatersrand, Johannesburg, 2000, South Africa \\ ${ }^{3}$ MM "Dniprovske", PJSC "DTEK Pavlohradvuhillia”, Pavlohrad, 51400, Ukraine \\ ${ }^{4}$ MM “Heroiv Kosmosu”, PJSC “DTEK Pavlohradvuhillia”, Pavlohrad, 51400, Ukraine \\ *Corresponding author: e-mail kovalevska_i@yahoo.com, tel. +380503328585
}

\begin{abstract}
Purpose. The purpose is to develop the calculation methods for minimizing the load on the fastening system of the preparatory mine working in difficult mining and geological conditions of its maintenance.

Methods. By analysing the multivariate computational experiments on the study of the stress-strain state of the load-bearing elements of the "massif - support" system in the preparatory mine workings by means of the finite-element method, as well as mine observations and measurements of displacement in the coal-overlaying rock formation.

Findings. An algorithm has been developed for searching the rational modes of the fastening system resistance and methods for minimizing the load on the support of the preparatory mine working, maintained in very complex mining and geological conditions.

Originality. The methodical principles have been developed of minimizing the load on the fastening system of the preparatory mine working, which are based on the use of a combination of stress-strain state studies of the "massif - support" system by means of the finite element method and provisions of normative documents for calculating the dimensions of the dome of natural equilibrium of the mine working roof rocks.

Practical implications. The operation modes optimisation of the load-bearing elements interaction of the mine working fastening system reduces the material and labour costs during its construction and increases its stability during operation.

Keywords: analysis, calculation, optimization, support, preparatory mine working, stope works, roof rocks, collapse

\section{Introduction}

The prediction of rock pressure for underground workings has been a major issue in excavation support design. Current research of geomechanical processes in working areas is focused on solving this problem [1]-[3]. The modern methods of predicting rock pressure manifestations are constantly being improved to fully account for the peculiarities of the interaction between support and the rock massif which encloses the mine working, together with its physical and mechanical properties [4]-[7]. These studies are crucial for the development of a general concept about the "massif support" system interaction and surveying the optimal parameters of this interaction. This takes into account the ultimate goal, which is to ensure stability of the mine workings using cost-effective technologies [8], [9]. Even though there are geological, mining and technical factors affecting the roadways design and their maintenance [10], [11], the fas-

tening process should be completely related to the geomechanics of border rock massif. The relationship between stress and fastening strength during roof support has been extensively dealt with by [12].

According to [12], [13], the main provisions have been substantiated by the loading process on fastening systems of the preparatory mine workings in the zone of the stope works. Schemes of conjunctive influence have been developed on the deformation-strength characteristics of lowering rocks of the roof (with their structural disturbances) and fastening constructions with different resistance modes. At this stage of the research, a transition from the overall qualitative pattern of such an interaction to quantitative assessments of parameters is deemed necessary [14], [15]. This is to develop methods of determining the rational deformationstrength characteristics of a fastening system and its main constituent components depending on the geomechanical factors of maintaining the preparatory mine work-
\end{abstract}


ing [16], [17]. In accordance with the research purpose, the first stage involves developing an algorithm to search for the rational modes of interaction between the fastening system and strengthened roof rocks. The roof rocks can be strengthened by resin-grouted roof bolts and cable bolts [18]. This includes performing a series of related studies with common parameters of the interaction process:

- the quality of the operation mode on the fastening system suggest the amount of load anticipated to be acting on it in specific mining and geological conditions of the mine working maintenance. The matching of the deformationstrength characteristics of the roof rocks and the fastening system can be done using the basic principles represented in research work [13]. Therefore, it is necessary to quantitatively determine the functions of each separately.

- for a specific rational mode of a fastening system operation, it is necessary to select a corresponding deformationstrength characteristics of each main load-bearing elements that constitutes the fastening system. The selection is performed based on the general rational function of the fastening system, but it also takes into account the moment of erecting the studied element. For example, setting the central prop stays of the strengthening support [19], [20].

- the structural parameters of fastening elements should be optimized meaning that it is practical to select a rational operation mode of each fastening element in terms of minimizing the material consumption. This allows the even distribution of resistance in proportion to the load-bearing capacity so as to satisfy a strength uniformity condition on the fastening structure when withstanding rock pressure [21].

The three listed positions are performed simultaneously and are extremely complex in their specific implementations. A number of schematic representations is required to simplify the task. This will result in predictable inaccuracies to assist in making the final recommendations. According to [22], [23], complex multivariate computational experiments based on the widely tested numerical finite element method could be a solution to the problem. The main reason for researching on rational parameters of the fastening system is as follows:

The fundamental difference between the finite element method (FEM) and the traditional analytical methods is that FEM covers any massif volume [24]-[26]. Again, introducing certain conditions at the boundaries of various elements of a model can make the following possible:

- constructing a coal-bearing massif structure with corresponding mechanical properties and critical discontinuities such as stratification of lithotypes, their breaking down into blocks in certain areas, etc. This makes it possible to model adequately the displacement of the coal-overlaying formation at different structure variants;

- to implement the deformation conditions compatibility between the border massif and fastening system elements of an extraction mine working, which is the most important zone of the stope works influence. This aspect makes it possible to consider the mutual influence of the stress-strain state (SSS) of border rocks and support which is necessary when calculating the deformation-strength characteristic of the rocks of the dome of natural equilibrium.

An advantage of the FEM method is that it is not necessary to separately calculate the deformation-strength characteristics, which three groups include: the weakened massif, the rocks of the dome of natural equilibrium and the fastening system. When calculating the FEM, the principle of their joint deformation is already considered, which allows automatic assessment of the following:

- influence of the deformation-strength characteristic of the fastening system $P(u)$ on the deformation-strength characteristic of the weakened massif as shown in Figure 1;

- influence of $P(u)$ on the deformation-strength characteristic of rocks of the dome at natural equilibrium as shown in Figure 2.

(a)

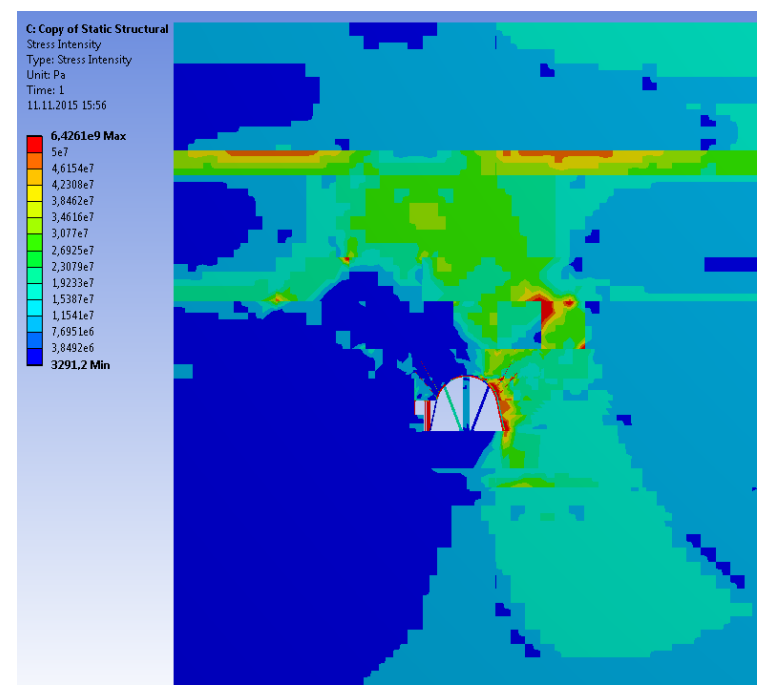

(b)

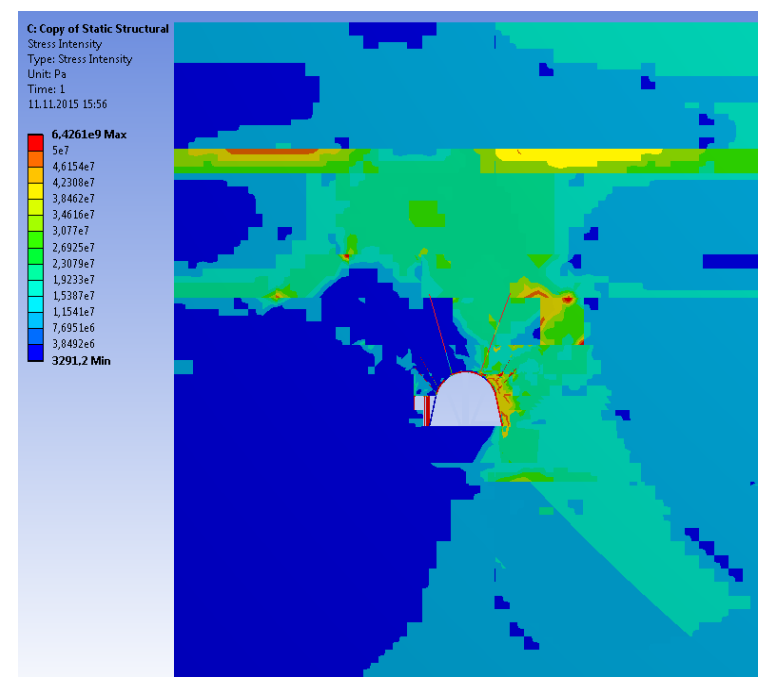

Figure 1. An example of stresses intensity curves in a coal-bearing rock stratum around the drift: the basic variant strengthening of each frame by four central prop stays and additional roof strengthening with bearing roof-bolt fastening (a) and recommended variant - strengthening the roof by combined roof-bolting system (b) in combination with resin-grouted roof bolts and rope bolts $(H=60 \mathrm{~m}$; roof bolts length $-2.4 \mathrm{~m}$; cable bolts length $-6.0 \mathrm{~m}$ )

Nevertheless, the main task remains to look for a twoparameter scheme of the optimal point $A$ of stabilization of the fastening system loading and its related parameters such as resistance $P_{A}$ and yielding property $u_{A}$. This is done by setting out the variants of computational experiments whilst varying the structural and operating parameters of the fastening system. 


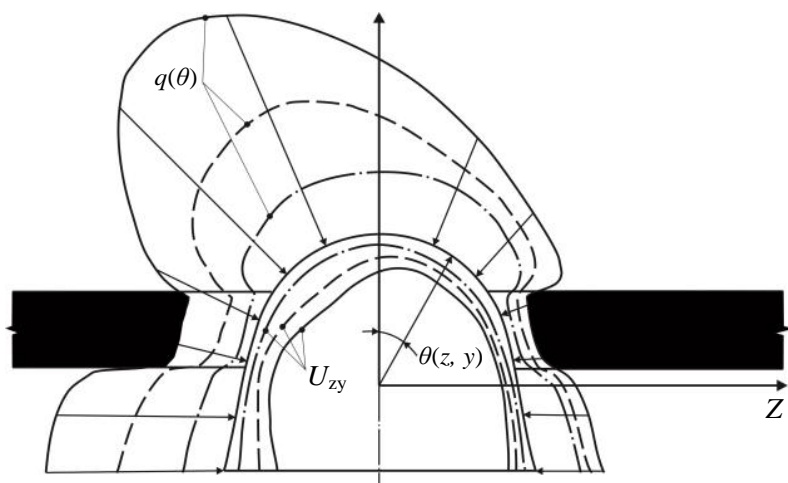

Figure 2. The scheme, generalized according to the computational experiments results, of development of rock pressure manifestations along the contour $\theta(z, y)$ of the preparatory mine working in the process of approaching the stope face (formation of a dome of natural equilibrium of rocks): $U_{z y}$ - the mine working contour displacement and $q(\theta)$ - the fastening system load: - - at the beginning of the bearing pressure zone; - - - in the middle of the bearing pressure zone; - before the stope face

When setting out the variants for each of the identified structure types of coal-overlaying formation, the SSS of the fastening system is assessed based on its main load-bearing elements, taking into account the strength uniformity condition.

On the other hand, despite the advantages of the FEM method, two peculiarities should be considered relating the deformation-strength characteristics of the weakened massif and the rocks of the dome of natural equilibrium. The numerous analytical studies present a relatively weak influence of the fastening system reaction on the constraint of rock contour displacements of mine working [27]-[29]. The influence level ranges between $3-15 \%$ with various combinations of geomechanical factors and the value of repulsive reaction of support. An approximately equivalent degree of influence can be observed in SSS studies of the geomechanical systems by means of FEM method (Fig. 1). Thus, the deformationstrength characteristic $q_{1}(u)$ of the weakened massif is exposed to restricted influence of the deformation-strength characteristic $P(u)$ of the fastening system. Again, the peculiarity is that the reaction is very sensitive to the value of the yielding property of the fastening system and, with relatively small variation, the value $P$ may change significantly. This fact is described in detail in previously developed schemes [13]. Hence, a relatively small SSS conversion of a weakened massif with a change in the fastening system reaction can result in a significant SSS conversion of the fastening system when varying the yielding property value. This provides an effective tool for optimizing the fastening system and its deformation-strength characteristic.

The second peculiarity relates to the deformation-strength characteristic $q_{2}(u)$ of rocks of the dome of natural equilibrium. In this case, the experience of solving elastic-plastic tasks by means of FEM method demonstrates the restricted influence of the fastening system reaction on the SSS change in the adjacent rock massif in areas where the formation of a dome of natural equilibrium is predicted [30]-[32]. The authors' opinion is that this scenario is conditioned by use of the computational experiment of a bound medium model. The bound model does not describe entirely the state of weakened and loosened rocks inside the dome, which lose stability and create a load on the fastening system with their weight. This rock volume behaviour is expected to be simulated according to the complete diagram of its deformation, including the super-limiting stages of its state [28]-[33]. This model of mine rock behaviour is extremely complex, but it was successfully solved for a single mine working [34]. From this mine, it can be shown that at the stage of the socalled "ruin" destruction, high rock contour displacements of the mine working are developed, which are very sensitive to the value of the fastening system reaction. Therefore, the graphs in a two-parameter scheme, which describe the deformation-strength characteristic of rocks of the dome of natural equilibrium are inclined at a smaller angle on the developed schemes [35]. That is, when changing the yielding property of the fastening system, the load on it from the weight of the rocks in the dome is changed less intensively than for the graph of the deformation-strength characteristic of the weakened massif. The main point of this influence of the fastening system reaction is revealed in the work by [28], where the possibility of stabilizing the unstable state of weakened rock is proven. This is achieved by the so-called "little impacts", which are comparable to the value of the fastening system reaction.

It is also necessary to reflect an inhomogeneity of the disturbed massif structure and a combination of fastening elements in the system of mine working maintenance. In view of the extreme complexity of performing a computational experiment with the use of a complete diagram of mine rock deformation, the following compromise has been proposed: it is recommended to determine the deformation-strength characteristic of rocks of the dome of natural equilibrium by the experimental-analytical methods described in the normative documents [35], [36]. It reflects quite objectively that the function $q_{2}(u)$, which causes the value of load on the fastening system (depending on the rock contour displacements of the drift) to be identical to the yielding property of support. In underground construction mechanics, modeling methods allow to determine the main qualitative elements, i.e. strain and failure processes mechanism of rocks during stoping. These are important steps in the process of hypotheses and theories development.

\section{Algorithm development and testing using coal mine workings as an example}

\subsection{Algorithm for searching the rational modes of the fastening system resistance in the preparatory mine working}

Summarizing the methodological aspects of a number of existing studies, the algorithm for assessing the rational parameters of the fastening system of the preparatory mine workings includes the following positions:

- the interaction of the deformation-strength characteristics of the weakened rock massif with the fastening system should be studied with the use of the FEM method in the elastic-plastic formulation;

- searching for a rational equilibrium state is performed based on joint consideration of the deformation-strength characteristic of a weakened massif $q_{1}(u)$ which can be determined by the FEM method, and the deformation-strength characteristic of rocks of the dome of natural equilibrium $q_{2}(u)$, determined according to the normative technique [35], [36];

- optimization of the deformation-strength characteristic of the fastening system is performed on the basis of FEM 
method calculations taking into account of the function $q_{2}(u)$ of the deformation-strength characteristic of rocks of the dome of natural equilibrium;

- optimization of parameters of the fastening system elements takes into account the condition of their strength uniformity which is performed based on their SSS study using the FEM method.

\subsection{Methods for minimizing the load on the support in the preparatory mine working}

According to the set algorithm for assessing the rational operation modes of the fastening system, the definition has been specified to a critical point $\mathrm{A}$ on the graphs intersecting in a two-parameter optimization scheme. This point characterizes the choice of the value of yielding property $u_{A}$ of support, at which the load $P_{A}$ acting on it will be decreased to minimum value in these mining and geological conditions of mine working maintenance. In an attempt to carry out this task, several methods have been developed to minimize the load on the fastening system, the essence of which is as follows.

It has been proven earlier that the criterion for minimizing the load is to achieve a condition where loads are equal according to the displacement factor of a weakened adjacent massif $q_{1}$ and based on the factor of formation of a dome of natural equilibrium $q_{2}$. For this purpose, it is necessary to calculate both components of the dependence according to a two-parameter optimization scheme in each specific case of the mine working maintenance. The order of determining specified dependencies is described sequentially.

Firstly, the deformation-strength characteristic of a weakened massif is determined by multivariate calculations of SSS using the FEM method of the "massif - support" geomechanical system as follows. The initial data such as the structure and properties of the coal-bearing strata, as well as the fastening system parameters are kept constant. However, only the value of the yielding property $u$ of the frame support is a subjected to variations. The range of yielding property change is looking at the fact that mine working is located in the zone of the stope works influence, what dramatically changes the rock mass structure [37], [38]. Again, the measurements of the rock contour displacements of the drift represents their maximum values in the period after the stope face passage at the boundary with the area of rock pressure stabilization [39], [42]. Generally, as a rule, a distance of 40-60 m behind the longwall face is adopted, however sometimes this distance is higher up to 160-200 $\mathrm{m}$ [38]. The analysis of results from various underground investigations, together with the measurements of rock contour displacements in the preparatory mine working shows that the changes in the yielding property of support varies with the mining and geological conditions. The range of changes of the working's dimensions in the most favorable conditions is up to $300 \mathrm{~mm}$, whereas in difficult conditions, the changes are up to $1100 \mathrm{~mm}$ and in very poor conditions in the areas with multi-seam mining can reach even $2100 \mathrm{~mm}$ [37]. In this range, more than five discrete values are established of the rock contour displacements $u$ of the mine working, for which the value $q_{1}$ of load on the support is determined. As a result, based on the combination of points with coordinates $\left(q_{1}\right)_{j}$ and $u_{j}$, a graph is constructed of the deformation-strength characteristic $q_{1}(u)$ of a weakened rock massif.

It is worth noting that the mining-geological and miningengineering conditions for maintaining the preparatory mine working are held fixed, so its rock contour displacements will be constant and are the only values in a specific computational experiment. Therefore, the question arises on how to change the yielding property of the frame and fastening system as a whole? When analyzing the available techniques for constructing the geomechanical models and conducting computational experiments such as changing the deformation characteristics of the frame yielding joists, fastening materials, operating parameters of fastening elements, etc., the choice has been made in favor of the following technique. Along the drift contour on the roof and sides, a layer with variable deformation characteristics of material is placed which changes the yielding property of the fastening system as a whole:

- the starting point is the yielding property of the fastening system without making changes to its structural and operating parameters; at the same time, the artificial layer along the mine working contour is attributed with the properties of the lithotypes occurring here and its "interference" into the yielding property of the fastening system is reduced to zero;

- to reduce the yielding property of the fastening system, the rigidity of the artificial layer is increased by increasing its deformation characteristics;

- to increase the yielding property of the fastening system, the deformation characteristics of the artificial layer is reduced. Again, the total "virtual" yielding property, which is assigned to the fastening elements, will contain the true yielding property and the compression value of the easily deformable layer.

In the analysis of the range of changing the predicted rock contour displacements of mine workings behind the longwall face, the technology of reducing the yielding property of the fastening system is unlikely to be used due to the active stope works influence. At the same time, in difficult mining and geological conditions, the sagging roof is mainly affected by the upper boundary of the determined range of $1100 \mathrm{~mm}$. By deducing the design yielding property of a frame of $300 \mathrm{~mm}$, it is necessary to increase the yielding property of the fastening system by $800 \mathrm{~mm}$. For this purpose, an artificial layer with a thickness of $1.0 \mathrm{~m}$ is introduced into the geomechanical model made up of a material with low deformation properties to allow the absorption of $800 \mathrm{~mm}$ under compression. Thus, by changing the deformation characteristics of the artificial layer from the values corresponding to the border rocks to the minimum values corresponding to a compression of $800 \mathrm{~mm}$, there is a possibility of modelling the different yielding properties of the same fastening system in specific mining and geological conditions.

According to the variable yielding property value of the fastening system, the value of the load $q_{1}$ should be determined for each its value. In a two-parameter formulation of an optimization scheme, the load $q_{1}$ is represented as the sum of vertical stresses $\sigma_{y}$, distributed along the mine working contour per unit length [39]-[43], [44]. The task of determining the curve $\sigma_{y}$ along the drift contour is easily performed after conducting a computational experiment with a hold fixed value of the yielding property of fastening system as shown in Figure 3. As a result, the second coordinate $q_{1}$ is obtained which is used to determine the $j$-th point $\left(q_{1}\right)_{j}, u_{j}$ on the plane in the parameters $\left(q_{1}, u\right)$, for the subsequent construction of a dependence, which reflects the deformationstrength characteristic $q_{1}(u)$ of the weakened massif. 


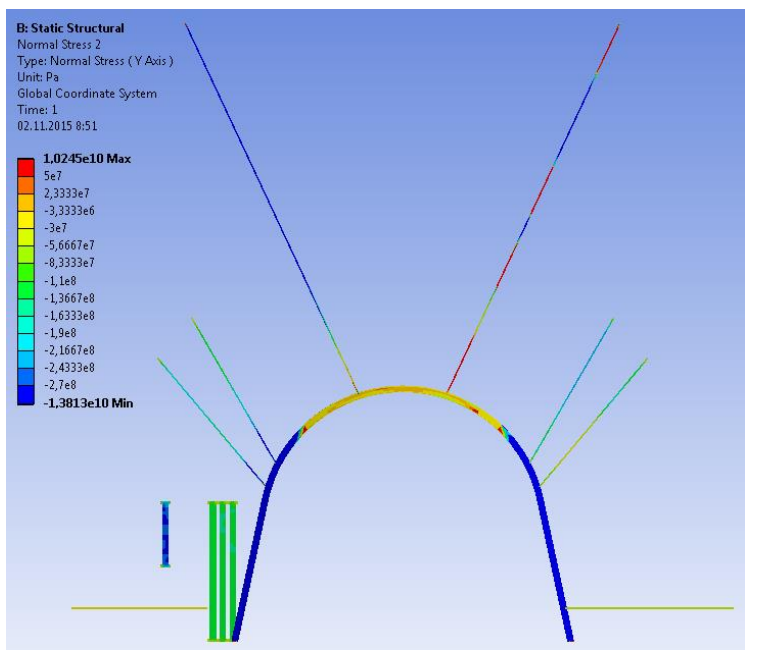

Figure 3. The curve of vertical stresses $\sigma_{y}$ distribution for recommended scheme of the drift maintenance

To improve the accuracy of the geomechanical model SSS, calculations can be performed in an elastic-plastic formulation involving the bilinear deformation diagram of both mine rocks and fastening materials. This makes it possible to consider the occurrence of the limiting state in unspecified model areas, which is accompanied by plastic flow of steel fastening elements and quasi-plastic deformation of mine rocks, provided that their volume is constant. This fact increases the displacement of the rock contour of the model and constrains the degree of "interference" of the artificial easily deformable layer into the process of displacement.

In the described sequence, the deformation-strength characteristic $q_{1}(u)$ is determined under specific mininggeological and mining-engineering conditions for maintaining the extraction mine workings. Based on the works by [13], [43], it should be noted that the following geomechanical factors influence significantly: depth $H$ of mine working location; the calculated resistance of roof rocks $R^{r}$ and bottom rocks $R^{b}$ of the coal seam. These can be used in the integral form to evaluate the strength properties of the coal-bearing stratum. According to the normative document SOU (2008), these are the most objective indicators in the zone of the stope works influence; the structure of an adjacent massif should be more than $20 \mathrm{~m}$ in height of the roof and the depth of the seam bottom, taking into account the influence of the weakening factors like water-cut, fracturing and rheology; the degree of rigidity of the collapsed rocks in the mined-out space [13].

The above-mentioned factor is formed by a small number of lithotypes such as sandstone, siltstone, argillite, coal, etc of the immediate and main roof rocks. Generally, these rocks occur in thick formation consisting of zones of uncontrolled collapse and hinged-block displacement. It should also be noted that when the total thickness of the mentioned zones of more than 12-15 m of extracted thicknesses of the seam, they are represented by rocks with different mechanical characteristics. This fact to some extent considers the average of deformation properties of the collapsed rocks which makes it possible to take them as constant, thereby excluding them from a number of variable factors.

The geomechanical factors are the structure of an adjacent coal-bearing stratum with planes of weakness, fracturing and water-logged lithotypes. In the course of studies by [31], three groups of conditions have been identified according to the degree of complexity of maintaining the extraction mine workings for their everyday use. In these studies, the proposed grouping of mining and geological conditions is taken into account when forming three series of multivariate computational experiments, each of which reflects its generalized structure of the adjacent coal-bearing stratum.

Two closely related factors remain the depth $H$ of mine working and integral strength characteristics of the roof $R^{r}$ as well as the bottom $R^{b}$ of an adjacent coal-bearing stratum. According to the related document by [35], these two are combined to get the average index given by $R=0.5\left(R^{r}+R^{b}\right)$. The tendencies to influence the geomechanical parameters $H$ and $R$ are both opposite and in the mining-engineering literature they are often classified as one index $H / R$. This does not only satisfy the various studies in the development of geomechanical processes around mine workings, but also reduces the number of mining-geological factors under consideration by one unit. The results of the SSS analysis of fastening systems presented earlier confirm that the parameters $H$ and $R$ on the state of fastening elements have an impaction the patterns. Therefore, the specified geomechanical parameters are combined into one index $H / R$, which is subsequently used to solve the set tasks. Another argument supporting this approach is the elastic-plastic formulation of the task, whereby step-by-step algorithm of calculations are performed with a gradual increase in the value of hydrostatic pressure on the model. This is equivalent to an increase in the depth $H$ of mine working location. Since the parameter $H$ is included into the index $H / R$, there is a possibility of its gradual change within a single computational experiment. Thus, in the methodical plan the following sequence of actions is implemented:

- a specific structure with mechanical characteristics of the coal-bearing massif is simulated, with parameters hold fixed onto the fastening system in the preparatory mine working;

- the range of changing the mine working depth $H$, for example, from 200 to $600 \mathrm{~m}$, covers significantly the actual conditions of mining operations performance [29], [31], [32], [45]. This is adopted when doing the present research;

- according to the technique by [36], the average calculated compressive resistance $R$ of an adjacent coal-bearing stratum can be determined;

- several values are accepted (usually more than five) of the index $H / R$ in the investigated range of variation $200 \mathrm{~m} \leq H \leq 600 \mathrm{~m}$;

- for each fixed value of $H / R$, a number of SSS calculations are performed with different values of yielding property $u$ of the fastening system and a group of lines 1 is constructed, which reflects the deformation-strength characteristic $q_{1}(u)$ of the weakened massif.

As a result, for a specific structure variant of the coalbearing massif and the fastening system of a mine working, a set of graphs is obtained at different values of index $H / R$. This significantly reduces the computational and time resources required to obtain the patterns of link between the function $q_{1}(u)$ and the index $H / R$.

Another significant geomechanical factor is the structure of an adjacent coal-bearing massif. The structure variation can be systematized and grouped into some averaged types according to studies [31], [45], [46] proposed that "a separation of mining and geological conditions according to the degree of complexity in repeated use of extraction mine workings". This work is closely related to the current studies on optimizing the interaction modes of the fastening system 
of reusable mine workings with the surrounding massif. A justifiable decision has been made to use the principle of grouping the mining and geological conditions in terms of the averaged structures of the adjacent coal-bearing stratum. These groups are discussed below:

- group I-the most unfavorable conditions for the maintenance of reusable extraction mine workings. It is characterized by predominantly thin-bedded structure of soft rocks $(f<1.5)$, layers of argillite and siltstone with a thickness of more than $1.0 \mathrm{~m}$ and an average distance of up to $1 \mathrm{~m}$ between the surfaces of weakening and layers of argillite and siltstone $(f=1.5-2.5)$ of medium thickness, which are periodically separated by water-flooded coal interlayers with a thickness of 0.1-0.3 m;

- group II - the conditions of medium intensity of rock pressure manifestations. It is characterized by thin-bedded and medium-bedded structure of water-free rocks with a hardness coefficients of argillite and siltstone ranging from $f=1.5-2.5$. It also has medium-bedded and thick-bedded structure of water-flooded rocks $(f>1.5)$ with sandstone having a thickness of up to $3.0 \mathrm{~m}$ ";

- group III - most favorable conditions for the repeated use of extraction mine workings. It is characterized by medium-bedded and thick-bedded structure of water-flooded rocks $(f>2.5)$ with sandstone occurring with a thickness of more than $3.0 \mathrm{~m}$. It also has medium-bedded and thickbedded structure of water-free rocks $(f>2.5)$.

The separate series of computational experiments is performed according to these three structure groups of an adjacent massif. As a result three groups of graphs are obtained which reflect the deformation-strength characteristic $q_{1}(u)$ of the weakened massif. This allows for the monitoring of the influence of geomechanical factors on changing the function $q_{1}(u)$. An analysis of the fastening schemes and maintenance schemes for reusable extraction mine workings emphasises the value of the approach [31], [39]. Therefore, it is impractical to monitor the influence of each of the used schemes due to the following reasons:

- firstly, the influence of the fastening system reaction $P$ on constraining the value of the mine working contour displacements $u$ is weak and usually amounts to a small percentage in the most widely used fastening schemes;

- secondly, recommended that a limited number of typical schemes for maintaining the preparatory mine workings, among which a fastening system has been chosen for group II with a medium intensity of rock pressure manifestations. This choice has been made intentionally to allow the expansion the range of optimization of the deformation-strength characteristic $P(u)$ of the fastening system, to increase its rigidity as well as the yielding property;

- thirdly, the computational experiments should be conducted using the same fastening system to maintain the accuracy.

Based on these principles, an algorithm has been developed for determining the deformation-strength characteristic $q_{1}(u)$ of a weakened massif, depending on the most influencing geomechanical factors.

The second component of the optimization scheme is the deformation-strength characteristic $q_{2}(u)$ of rocks of the dome of natural equilibrium. The calculation methods are represented by equation (1). When substantiating an algorithm for searching the rational modes of the fastening system resistance, the expediency of using the normative technique has been proven [36]. This makes it possible to link directly the load $q_{2}$ from the dome of natural equilibrium and the displacements $u$ of the rock contour of the drift by means of the functional dependence $q_{2}(u)$. To determine the function $q_{2}(u)$, the known ratios of the technique by [36], were used with some transformations and simplifications connected with the specification of the region. The fastening schemes and protection of the preparatory mine working with the most relevant area which is the zone of the rock pressure stabilization behind the longwall face. The design fundamentals have been used according to the approach by [31].

When performing the mathematical transformations, a linear function of the deformation-strength characteristic $q_{2}(u)$ has been set of rocks of the dome of natural equilibrium:

$q_{2} u=K_{d} B \gamma \frac{1-\alpha_{1}^{2}}{0.15+0.03 \alpha_{2}-0.18 \alpha_{1}} u$

where:

$K_{d}$-dynamic factor, which takes into account conventional instantaneous displacements of massif around the extraction mine working; it is determined based on the recommendations [36];

$B$ - the depth of mine working during driving;

$\gamma$-the weight-average unit specific gravity of rocks in the dome of natural equilibrium;

$a_{1}$ and $a_{2}$-parameters, setting the ratio between the lowering of the mine working roof in the areas: outside the zone of the stope works influence; in the zone of frontal bearing pressure of approaching longwall face; behind the stope face in the zone of stabilization of the rock pressure manifestations.

The parameters $a_{1}$ and $a_{2}$ have been obtained based on the calculated equations from [36], by transforming them for the solved task of determining the function $q_{2}(u)$ :

$$
\begin{aligned}
& \alpha_{1}=\frac{1.5 R_{1}^{b} R_{3}^{r}+R_{3}^{b}}{3.0+2 m R_{3}^{b} R_{1}^{r}+R_{1}^{b}} ; \\
& \alpha_{2}=\frac{3.9 R_{2}^{b} R_{3}^{r}+R_{3}^{b}}{3.9+2 m R_{3}^{b} R_{2}^{r}+R_{2}^{b}},
\end{aligned}
$$

where:

$m$ - the extracted thickness of the coal seam;

$R_{1,2,3}^{r, b}$ - the calculated values of compressive resistance of roof rocks and bottom rocks of the coal seam in the appropriate areas include: outside the zone of the stope works influence; in the zone of frontal bearing pressure; behind the longwall face. It is determined by the technique from [36], in addition to work from [31].

When determining the deformation-strength characteristic $q_{2}(u)$ of rocks of the dome of natural equilibrium, the methodological provisions based on the normative geomechanical phenomenon have been adopted, such as constraining the dimensions of the dome by means of the fastening system reaction [36]. The theoretical principle of this phenomenon was substantiated in the work by [28], where it has been proven that the rock volumes can be brought out to a stable state from an unstable state by the so-called "little impacts" such as the support reaction to the acting stresses. These volumes are then excluded from the process of loading the fastening system in the preparatory mine working. 
In practical, to determine the degree of constraining the load and displacements of the rock contour, the methods and results of studies by [43], [44] have been used to optimize the interaction modes of mine workings support with the rock massif. A complex of calculations has been performed on the existing methods, and dataset obtained is summarized in Table 1.

Table 1. The values of coefficient $K_{p}$ of influence of the fastening system reaction, \%

\begin{tabular}{ccccccc}
\hline $\begin{array}{c}\text { Weight-average } \\
\text { compressive re- } \\
\text { sistance of the dome } \\
\text { rocks } R_{c r}, \mathrm{MPa}\end{array}$ & 50 & 100 & 150 & 200 & 250 & 300 \\
\cline { 2 - 7 } & 4.2 & 9.6 & 15.6 & 22.1 & 28.8 & 35.9 \\
10 & 3.0 & 6.8 & 11.1 & 15.6 & 20.4 & 25.4 \\
15 & 2.5 & 5.6 & 9.1 & 12.9 & 16.8 & 20.9 \\
20 & 2.1 & 4.8 & 7.8 & 11.0 & 14.4 & 18.0 \\
30 & 1.7 & 3.9 & 6.4 & 9.0 & 11.7 & 14.6 \\
40 & 1.5 & 3.4 & 5.5 & 7.8 & 10.2 & 12.7 \\
\hline
\end{tabular}

In the construction of Table 1, it has been taken into account that the constraint value of the displacements and loads, presented in a relative form by a coefficient $K_{p}$, is not only influenced by the fastening system reaction $P$. It is also influenced by the weighted-average compressive resistance of rocks in the unbroken state and located in the dome of natural equilibrium. This process occurs in such a way that a decrease in $R_{c r}$ will result in an increase in the degree of influence of the support reaction. This result is in agreement with the principles of mine rocks mechanics which states that softer rocks require minimum principal stresses to take them out of the limiting state.

Taking into account of the influence of the fastening system reaction $P$, the equation for calculating the deformationstrength characteristic of rocks of the dome of natural equilibrium is transformed as follows:

$$
q_{2} u=K_{d} B \gamma \frac{1-\alpha_{1}^{2}\left(1-\frac{K_{p}}{100}\right)}{0.15+0.03 \alpha_{2}-0.18 \alpha_{1}} u,
$$

where:

$K_{p}$ - the coefficient of influence of the fastening system reaction on the constraint of the roof rocks lowering of the preparatory mine working, \%; it is determined by Table 1 .

As a result, the methods have been developed for determining the deformation-strength characteristic of a weakened massif $q_{1}(u)$ and rocks of the dome of natural equilibrium $q_{2}(u)$. These methods occupy dominant positions when optimizing the operation modes of the fastening system of the preparatory mine workings. To set the patterns of link between the optimal values $P_{A}$ and $u_{A}$ with geomechanical factors for maintaining the extraction mine workings, a complex of calculations is performed for all the three structure groups of an adjacent coal-bearing massif with variation of the $H / R$ index. The data obtained is processed by the methods of correlationdispersion analysis. The functions $P_{A}(H / R)$ and $u_{A}(H / R)$ are the end results for the three generalized structures of the coaloverlaying formation. The developed methods of obtaining the patterns $P_{A}(H / R), u_{A}(H / R)$ enables the determination of the conditions of the minimum load formation on the support, under which the optimization of the deformation-strength characteristic of the fastening system is made.

\subsection{Testing of calculation methods for minimizing the load on excavation support}

According to the developed methods, complex of multivariate computational experiments has been carried out to determine the deformation-strength characteristic $q_{1}(u)$ of a weakened massif and calculations have been performed of the deformation-strength characteristic $q_{2}(u)$ of rocks of the dome of natural equilibrium. To put to practice the technology of performing the search for minimization of the load $q_{A}$ on the fastening system with appropriate yielding property $u_{A}$, preliminary (test) calculations of functions $q_{1,2}(u)$ have been performed in the areas of boundary values of geomechanical parameters that characterize favorable and complex mining-geological conditions of maintaining the extraction mine workings. This is demonstrated in Figure 4.

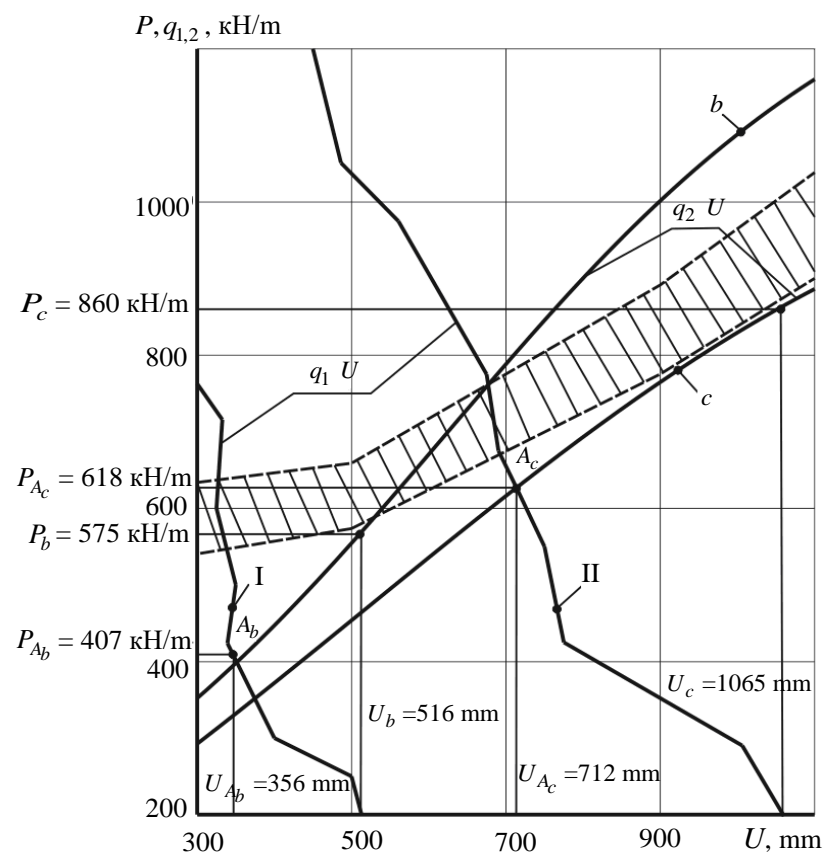

Figure 4. To the analysis of accuracy and adequacy of the methods for optimizing the interaction modes between the fastening system and the surrounding massif: $I-H / R=9.6 \mathrm{~m} / \mathrm{MPa}$; $I I-H / R=88.9 \mathrm{~m} / \mathrm{MPa} ; " \mathrm{~b}$ ” $-\mathrm{B}=5.18 \mathrm{~m}, \mathrm{R}_{c r}=30.2 \mathrm{MPa}$; “c”-B $=4.50 \mathrm{~m}, \mathrm{R}_{\mathrm{cr}}=5.3 \mathrm{MPa}$; - - the boundaries of the range of loads on the yieldable support according to normative documents [35], [47], [48]

From Figure 4, the lines I and II denote the calculated results of the deformation-strength characteristic $q_{1}(u)$ of the weakened massif. These are performed using multivariate computational experiments, hence the dependencies are shown in the form of polylinear graphs. Each point of inflexion corresponds to a single computational experiment with a specific thickness of the artificial yieldable layer. The calculations have been performed for both the minimum (line I) and maximum (line II) values of the index $H / R$, which approximate to the boundaries of the studied range of mining and geological conditions. Therefore, the area enclosed between the I and II lines gives a sufficiently complete concept of the group of functions $q_{1}(u)$.

The deformation-strength characteristic of rocks of the dome of natural equilibrium is a fairly "smooth" function $q_{2}(u)$, which is calculated using Formula (4). The range of $q_{2}(u)$ variation at a fixed value of the rock contour displace- 
ment $u$ can be explained by the mining and geological conditions for maintaining preparatory mine working. It is justified by the standard size of its section and the degree of influence of the fastening system reaction on the constraint of the drift contour displacements. The presented range of the function $q_{2}(u)$ variation reflects the maximum array of probable situations when maintaining the mine working. These include: an increase in its depth $B$ at a sufficiently high value of the average compressive resistance $R$ of an adjacent rock massif which was calculated; a decrease in the mine working width due to the intense rock pressure impact on a smaller section with soft host rocks.

As shown in Figure 4, there is a main range of variation of the deformation-strength characteristics $q_{1}(u)$ and $q_{2}(u)$. The joint consideration makes it possible to determine the rational interaction mode between the fastening system and the surrounding massif. As previously noted, the point $A$ is one of the dominant positions in the optimization scheme. It has been determined for favorable and difficult mining and geological conditions of maintaining the preparatory mine workings as indicated by $A_{b}$ and $A_{c}$ respectively. The following optimization results have been obtained:

- in favorable conditions, the point $A_{b}$ which is an intersection of graphs "I" and " $b$ " is characterized by minimum load $P_{A b}=407 \mathrm{kN} \cdot \mathrm{m}$ with the yielding property $u_{A b}=356 \mathrm{~mm}$ of the fastening system;

- in difficult mining and geological conditions, the point $A_{c}$ which is an intersection of graphs "II" and " $c$ " has the following coordinates: $P_{A c}=618 \mathrm{kN} \cdot \mathrm{m}, u_{A c}=712 \mathrm{~mm}$.

From the results, it can be seen that the deterioration of conditions for maintaining the preparatory mine working has led to an increase in the minimum load on support by $51.8 \%$. At the same time, the optimal value of yielding property of the fastening system is doubled. The predominant increase in yielding property as compared to the load is owing to presence of intensive stratification and weakening of the roof rocks in the zone of the stope works influence. The increased yielding property of the fastening system is important for the "deviation" from excessive rock pressure. This conclusion is confirmed by the following examples (Fig. 4):

- assuming that the yielding property of the fastening system in favorable conditions is $u_{b}=516 \mathrm{~mm}$ which is $44.9 \%$ more than optimal value and the load increases to $P_{b}=575 \mathrm{kN} \cdot \mathrm{m}$ which is $41.3 \%$ more than the optimal value;

- similarly, in difficult mining and geological conditions, the yielding property is increased to $u_{c}=1065 \mathrm{~mm}$ which is $49.6 \%$ more than optimal value which in turn leads to an increase in the load to $P_{c}=860 \mathrm{kN} \cdot \mathrm{m}$ which is $39.2 \%$ more than optimal value.

It is prudent to emphasize the following tendencies. A fairly constant relative increase in the yielding property (44.9 and $49.6 \%$ ) of the fastening system led to a relatively constant increase in the load (41.3 and 39.2\%) regardless of the degree of complexity of conditions for maintaining the mine working. This can confirm indirectly the adequacy of the adopted initial provisions of the optimization scheme which states that the nature of the interaction mechanism between the support and massif is the same for different conditions of maintaining the preparatory mine workings.

Another important observation is that with a significant dispersion of geomechanical indexes $(H / R$ - by 9.26 times, $R_{c r}$ - by 5.70 times), the minimum possible load value $\left(P_{A b}\right.$ and $P_{A c}$ ) differs only by $51.8 \%$ for near boundary conditions of maintaining the preparatory mine workings. Such a conclusion emphasizes the importance of optimizing the interaction modes between support and rocks surrounding the mine working. With a significant deterioration in the conditions for maintaining the mine working stability, it is possible to ensure relatively small additional costs for fastening materials and their setting.

In order to assess the degree of certainty of the algorithm, the results have been compared with normative techniques [35], [47], [48]. The yielding property of support as a reducing factor of the load $P(u)$, generally takes into account the range of changing the function $P(u)$ as shown in Figure 4 with dotted lines and shaded. The task of optimizing the interaction modes between the support with the surrounding massif is not solved in the mentioned methods. Therefore, the load on the yieldable support is significantly higher than the optimal values $P_{A b}$ and $P_{A c}$, but to a certain extent corresponds to the considered examples of non-optimal operation modes of the support with increased yielding property. Thus, under favorable conditions, the optimal load $P_{A b}$ is 36.9 to $57.5 \%$ lower than the recommended one by [35], [47], [48]. In difficult mining and geological conditions, this deviation is approximately 10.8 to $27.5 \%$. Moreover, comparing the non-rational increase in the yielding property of the fastening system in the discussed examples, the load values are reduced by 3.7 to $19.4 \%$ under favorable conditions - and by 1.7 to $18.0 \%$ under difficult mining and geological conditions.

Two important conclusions can be drawn from this data. Firstly, the developed optimization scheme is effective in reducing the load on the fastening system by about $10-57 \%$. Secondly, with non-optimal interaction modes between support and rock massif, the differences with normative documents in the results of load calculations are reduced by $2-19 \%$ which is quite acceptable for mining-engineering calculations. It should be noted that the attempt to describe geomechanical systems, which has a significant discontinuity of geometric and mechanical parameters of its elements can create complexities in the finite equation. Hence, the development of an algorithm seems more appropriate than numerical methods of geomechanic systems research.

\section{Conclusions}

Several conclusions can be drawn from this research work. These include:

1. In terms of the main purpose of this research, the algorithm has been substantiated by searching of rational interaction modes of the fastening system with the coal-bearing massif surrounding the mine working. The algorithm includes conducting a number of studies that are closely related to each other by common parameters of the interaction process:

- formation of the lowest possible load in specific mining and geological conditions of the mine working maintenance;

- correlation of the deformation-strength characteristics of load-bearing elements with that of the fastening system;

- optimization of structural parameters of fastening elements by the criterion of their strength uniformity.

2. The methodical principles have been developed to minimize the load on the fastening system of the reusable preparatory mine workings. These are based on the use of various studies by means of the FEM method to determine the deformation-strength characteristic of a weakened massif and recommend on the normative documents for calculating 
the dimensions of the dome of natural equilibrium (deformation-strength characteristic of the dome rocks).

3 . Based on the set principles, the methods have been developed for determining the deformation-strength characteristics of a weakened massif depending on the most influencing geomechanical factors such as the depth of mine working location, the rocks structure of coal-overlaying formation and its strength properties. When determining the deformationstrength characteristic of rocks of the dome of natural equilibrium, the methodological provisions of the related documents have been modified and supplemented taking into account of a geomechanical phenomenon which is constraining the dimensions of the dome due to the fastening system reaction.

4. Testing the methodical principles of minimizing the load on the fastening system of extraction mine workings has confirmed their adequacy and certainty.

\section{Acknowledgements}

The authors express their gratitude to the management of DTEK Coal Unit for their help in organizing the experimental research.

\section{References}

[1] Liu, C., Li, H., Mitri, H., Jiang, D., Wang, G., Zhang, Z., \& Jing, W. (2019). Strata movement and shield pressure analysis at tongxin longwall top coal caving working face with extra-thick coal seam. Arabian Journal of Geosciences, 12(24), 786. https://doi.org/10.1007/s12517-019-4787-0

[2] Yang, H., Han, C., Zhang, N., Sun, C., Pan, D., \& Dong, M. (2019). Stability control of a goaf-side roadway under the mining disturbance of an adjacent coal working face in an underground mine. Sustainability, 11(22), 6398. https://doi.org/10.3390/su11226398

[3] Malanchuk, Z., Malanchuk, Y., Korniyenko, V., \& Ignatyuk, I. (2017). Examining features of the process of heavy metals distribution in technogenic placers at hydraulic mining. Eastern-European Journal of Enterprise Technologies, 1(10(85)), 45-51. https://doi.org/10.15587/1729$\underline{4061.2017 .92638}$

[4] Glushikhin, F.P., Shklyarskii, M.F., \& Bazhin, N.P. (1981). Predicting rock pressure manifestations in seam development workings. Soviet Mining Science, 17(2), 112-117. https://doi.org/10.1007/bf02498404

[5] Odintsev, V.N. (1995). Method of analytical prediction of dynamic rock pressure manifestations. Fiziko-Tekhnicheskie Problemy Razrabotki Poleznykh Iskopaemykh, (4), 12-24.

[6] Malanchuk, Z., Moshynskyi, V., Stets, S., Ignatiuk, I., \& Galiyev, D. (2020). Modelling hydraulic mixture movement along the extraction chamber bottom in case of hydraulic washout of the puff-stone. E3S Web of Conference, (201), 01011. https://doi.org/10.1051/e3sconf/202020101011

[7] Nazimko, V.V., \& Babenko, K.V. (2017). Spreading of ground pressure fluctuation in the gob. Proceedings of the 36th International Conference on Ground Control in Mining, 131-137.

[8] Abdiev, A., Mambetova, R., Abdiev, A., \& Abdiev, S. (2020). Development of methods for assessing the mine workings stability. E3S Web of Conference, (201), 01040. https://doi.org/10.1051/e3sconf/202020101040

[9] Babets, D.V., Sdvyzhkova, O.O., Larionov, M.H., \& Tereshchuk, R.M. (2017). Estimation of rock mass stability based on probability approach and rating systems. Naukovyi Visnyk Natsionalnoho Hirnychoho Universytetu, (2), 58-64.

[10] Małkowski, P., Niedbalski, Z., \& Majcherczyk, T. (2016). Roadway design efficiency indices for hard coal mines. Acta Geodynamica et Geomaterialia, 13(2(182)), 201-211. https://doi.org/10.13168/AGG.2016.0002

[11] Khalymendyk, I., \& Baryshnikov, A. (2018). The mechanism of roadway deformation in conditions of laminated rocks. Journal of Sustainable Mining, 17(2), 41-47. https://doi.org/10.1016/j.jsm.2018.03.004

[12] Kovalevska, I., Barabash, M., Husiev, O., \& Snihur, V. (2018). Interaction of deformation-strength characteristics of the support load-bearing elements in the preparatory workings. E3S Web of Conferences, (60), 00002. https://doi.org/10.1051/e3sconf/20186000002

[13] Bondarenko, V.I., Simanovich, G.A., Kovalevska, I.A., \& Fomichov, V.V (2007). Research of rock stresses and deformations around mining workings. Technical, Technological and Economic Aspects of Thin-Seams Coal Mining, 47-56. https://doi.org/10.1201/noe0415436700.ch6
[14] Dychkovskyi, R., Vladyko, O., Maltsev, D., \& Cabana, E.C. (2018). Some aspects of the compatibility of mineral mining technologies. $\begin{array}{lll}\text { Rudarsko-Geološko-Naftni } \quad \text { Zbornik, } & 33(4), & 73-82\end{array}$ https://doi.org/10.17794/rgn.2018.4.7

[15] Lozynskyi, V., Medianyk, V., Saik, P., Rysbekov, K., \& Demydov, M. (2020). Multivariance solutions for designing new levels of coal mines. Rudarsko Geolosko Naftni Zbornik, 35(2), 23-32. https://doi.org/10.17794/rgn.2020.2.3

[16] Abdiev, A.R. (2002). Evaluation of the stressed-strained state of rock massif for brown coal deposit. Gornyi Zhurnal, (10), 70-72.

[17] Majcherczyk, T., \& Niedbalski, Z. (2017). The impact of multiple seam mining exploitations on seismic activity and state of stress. Studia Geotechnica et Mechanica, 39(1), 53-62. https://doi.org/10.1515/sgem2017-0005

[18] Kuanyshbekovna, M.M., Krupnik, L., Koptileuovich, Y.K., Mukhtar, E., \& Roza, A. (2016). The system is "roof bolting-mountain". International Journal of Applied Engineering Research, 11(21), 10454-10457.

[19] Bondarenko, V., Symanovych, G., \& Koval, O. (2012). The mechanism of over-coal thin-layered massif deformation of weak rocks in a longwall. Geomechanical Processes During Underground Mining, 4144. https://doi.org/10.1201/b13157-8

[20] Kovalevska, I., Symanovych, G., \& Fomychov, V. (2013). Research of stress-strain state of cracked coal-containing massif near-theworking area using finite elements technique. Annual-ScientificTechnical Collection-Mining of Mineral Deposits, 159-164. https://doi.org/10.1201/b16354-28

[21] Mambetov, S.A., Mambetov, A.S., \& Abdiev, A.R. (2002). Zonal and step-by-step evaluation of the stressed-strained state of Tyan'-Shan' rock massif. Gornyi Zhurnal, (10), 57-62.

[22] Kovalevs'ka, I., Fomychov, V., Illiashov, M., \& Chervatuk, V. (2012). The formation of the finite-element model of the system "undermined massif - support of stope". Geomechanical Processes During Underground Mining - Proceedings of the School of Underground Mining, 73-80. https://doi.org/10.1201/b13157-13

[23] Shashenko, A., Gapieiev, S., \& Solodyankin, A. (2009). Numerical simulation of the elastic-plastic state of rock mass around horizontal workings. Archives of Mining Sciences, 54(2), 341-348.

[24] Gallager, R. (1984). Konechnyy element. Analiz. Moskva, Rossiya: Nedra, 428 p.

[25] Fadeev, A.B. (1987). Metod konechnykh elementov v geomechanike. Moskva, Rossiya: Nedra, 221 p.

[26] Lozynskyi, V., Saik, P., Petlovanyi, M., Sai, K., \& Malanchuk, Y. (2018). Analytical research of the stress-deformed state in the rock massif around faulting. International Journal of Engineering Research in Africa, (35), 77-88. https://doi.org/10.4028/www.scientific.net/jera.35.77

[27] Bondarenko, V., Kovalevska, I., Symanovych, G., Sotskov, V., \& Barabash, M. (2018). Geomechanics of interference between the operation modes of mine working support elements at their loading. Mining Science, (25), 219-235. https://doi.org/10.5277/msc182515

[28] Vinogradov, V.V. (1989). Geomekhanika upravleniya sostoyaniem massiva vblizi gornykh vyrabotok. Kiev, Ukraina: Naukova dumka, $192 \mathrm{p}$.

[29] Simanovich, G., Serdiuk, V., Fomichov, V, \& Bondarenko, V. (2007). Research of rock stresses and deformations around mining workings. Technical, Technological and Economical Aspects of Thin-Seams Coal Mining, International Mining Forum 2007, 47-56. https://doi.org/10.1201/noe0415436700.ch6

[30] Bondarenko, V., Cherniak, V., Cawood, F., \& Chervatiuk, V. (2017). Technological safety of sustainable development of coal enterprises. Mining of Mineral Deposits, 11(2), 1-11. https://doi.org/10.15407/mining11.02.001

[31] Pivnyak, G., Bondarenko, V., Kovalevs'ka, I., \& Illiashov, M. (2012). Geomechanical processes during underground mining. London, United Kingdom: CRC Press, Taylor \& Francis Group, 238 p. https://doi.org/10.1201/b13157

[32] Kovalevska, I., Vivcharenko, O., \& Snigur, V. (2013). Specifics of percarbonic rock mass displacement in longwalls end areas and extraction workings. Annual-Scientific-Technical Collection-Mining of Mineral Deposits, 29-34. https://doi.org/10.1201/b16354-7

[33] Baklashov, I.V., \& Kartoziya, B.A. (1986). Mekhanicheskie protsessy v porodnykh massivakh. Moskva, Rossiya: Nedra, 272 p.

[34] Pivnyak, G., Bondarenko, V., \& Kovalevska, I. (2015). New developments in mining engineering 2015: Theoretical and practical solutions of mineral resources mining. London, United Kingdom: CRC Press, Taylor \& Francis Group, 616 p. https://doi.org/10.1201/b19901

[35] KD 12.01.01.201-98. (1998). Raspolozhenie, okhrana i podderzhanie gornykh vyrabotok pri otrabotke ugol'nykh plastov na shakhtakh. Kyiv, Ukraina: Ukrainskyi naukovo-doslidnyi marksheyderskyi instytut, 149 p. 
[36] SOU 10.1.00185790.011:2007. (2008). Pidhotovchi vyrobky na polohykh plastakh. Vybir kriplennia, sposobiv i zasobiv okhorony. Standart Minvuhlepromu Ukrainy. Donetsk, Ukraina: Donetskyi vuhilnyi instytut, $116 \mathrm{p}$.

[37] Małkowski, P., \& Ostrowski, Ł. (2019). Convergence monitoring as a basis for numerical analysis of changes of rock-mass quality and Hoek-Brown failure criterion parameters due to longwall excavation. Archives of Mining Sciences, 68(1), 93-118. https://doi.org/10.24425/ams.2019.126274

[38] Majkherchik, T., Gajko, G.I., \& Malkowski, P. (2002). Deformation process around a heading investigation when front of longwall face advancing. Ugol, (11), 27-29.

[39] Symanovych, G., Demydov, M., \& Chervatuk, V. (2013). Influence mechanism of rock mass structure forming a stress on a face support. Annual-Scientific-Technical Collection-Mining of Mineral Deposits, 77-82. https://doi.org/10.1201/b16354-15

[40] Majcherczyk, T., Małkowski, P., \& Niedbalski, Z. (2008). Rock mass movements around development workings in various density of standing-and-roof-bolting support. Journal of Coal Science \& Engineering, 14(3), 356-360. https://doi.org/10.1007/s12404-008-0078-1

[41] Małkowski P., Niedbalski Z., Majcherczyk T., \& Bednarek Ł. (2020). Underground monitoring as the best way of roadways support design validation in a long time period. Mining of Mineral Deposits, 14(3), 114. https://doi.org/10.33271/mining 14.03.001

[42] Majcherczyk, T., Niedbalski, Z., Małkowski, P., \& Bednarek, Ł. (2014). Analysis of yielding steel arch support with rock bolts in mine roadways stability aspect. Archives of Mining Sciences, 59(3), 641-654. https://doi.org/10.2478/amsc-2014-0045

\section{Розробка і тестування алгоритму розрахунку навантаження на кріплення виробок}

\section{В. Бондаренко, І. Ковалевська, Ф. Кейвуд, О. Гусєв, В. Снігур, Д. Джиму}

Мета. Розробити методику розрахунку мінімізації навантаження на кріпильну систему підготовчої виробки у складних гірничогеологічних умовах ії підтримки.

Методика. Аналіз різноманітних обчислювальних експериментів 3 дослідження напружено-деформованого стану вантажонесучих елементів системи “масив - кріплення” підготовчих виробок методом скінченних елементів, а також шахтних спостережень і вимірювань зрушення надвугільної товщі порід.

Результати. Розроблено алгоритм пошуку раціональних режимів опору кріплення системи і методику мінімізації навантаження на кріплення підготовчої виробки, яка підтримується у досить складних гірничо-геологічних умовах.

Наукова новизна. Розроблено методичні засади мінімізації навантаження на кріпильну систему підготовчої виробки, що побудовані на використанні комбінації досліджень напружено-деформованого стану системи “масив - кріплення" за допомогою методу скінченних елементів і положень нормативних документів з розрахунку розмірів склепіння природної рівноваги порід покрівлі виробки.

Практична значимість. Оптимізація робочих режимів взаємодії вантажонесучих елементів кріплення системи виробки знижує матеріальні й трудові витрати при ії спорудженні та підвищує стійкість при експлуатації.

Ключові слова: аналіз, розрахунок, оптимізачія, кріплення, підготовча виробка, очисні роботи, породи покрівлі, обвалення

\section{Разработка и тестирование алгоритма расчета нагрузки на крепь выработок}

\section{В. Бондаренко, И. Ковалевская, Ф. Кейвуд, А. Гусев, В. Снигур, Д. Джиму}

Цель. Разработать методику расчета минимизации нагрузки на крепежную систему подготовительной выработки в сложных горно-геологических условиях ее поддержания.

Методика. Анализ многовариантных вычислительных экспериментов по исследованию напряженно-деформированного состояния грузонесущих элементов системы “массив - крепь” подготовительных выработок методом конечных элементов, а также шахтных наблюдений и измерений сдвижения надугольной толщи пород.

Результаты. Разработан алгоритм поиска рациональных режимов сопротивления крепежной системы и методика минимизации нагрузки на крепь подготовительной выработки, поддерживаемой в весьма сложных горно-геологических условиях.

Научная новизна. Разработаны методические принципы минимизации нагрузки на крепежную систему подготовительной выработки, построенные на использовании комбинации исследований напряженно-деформированного состояния системы “массив крепь” с помощью метода конечных элементов и положений нормативных документов по расчету размеров свода естественного равновесия пород кровли выработки.

Практическая значимость. Оптимизация рабочих режимов взаимодействия грузонесущих элементов крепежной системы выработки снижает материальные и трудовые затраты при ее сооружении и повышает устойчивость при эксплуатации.

Ключевые слова: анализ, расчет, оптимизация, крепь, подготовительная выработка, очистные работы, породы кровли, обрушение 